\title{
AKAP6 Gene
}

National Cancer Institute

\section{Source}

National Cancer Institute. AKAP6 Gene. NCI Thesaurus. Code C134587.

This gene is involved in the regulation of protein kinase A-dependent signaling. 